\title{
Potency of Chitosan and Chitooligochitosan (COS) from Marine Shrimp Shells as Prebiotics for Streptococcus thermophillus and Lactobacillus bulgaricus Probiotics
}

\author{
Ervia Yudiati ${ }^{*}$, Sri Sedjati' , Adha Susanto', Nuril Azhar', Rabia Alghazeer² \\ 'Marine Science Department, Faculty of Fisheries and Marine Science, Diponegoro University \\ J. Prof. H. Soedharto, SH. Tembalang, Semarang, 50275 Indonesia \\ 2Department of Chemistry, Faculty of Sciences, University of Tripoli \\ Tariq Sayyidi al Misri Road, Tripoli, Libya \\ Email: eyudiati@gmail.com
}

\begin{abstract}
Lately, chitosan as a result of chitin deacetilation has known as potencial compound as food industry, pharmacy and environmental agents. The weakness of chitosan is the low water solubility and high viscosity. The size reduction by cutting the $\beta-1,4$ glicosidic bond to improve the bioactivity is the alternative solution. This research aims to find out the addition of chitosan and COS for the Streptococcus thermophillus FNCC - 0041 and Lactobacillus bulgaricus FNCC - 0040 probiotics bacteria culture. S. thermophillus and L. bulgaricus were cultured in the MRS Broth media with addition of Commercial Chitosan (CC), Commercial Oligochitosan (COC), Self-production Chitosan (PC) and Self-production Oligochitosan (POC) in different doses $10.05 ; 0.1$; and $0.2 \mathrm{mg} . \mathrm{ml}$ 1). Percentage DD on those treatments was similar. The spectra vibration of The FT-IR analysis of PC and POC were fit to the CC and COC. In chitosan treatments, the best growth of S. thermophilus was reached at $0.2 \mathrm{mg} / \mathrm{mL} P C$, while in chitooligochitosan was from $0.20 \mathrm{mg} / \mathrm{mL} C O C$ treatments, respectively. The addition of different type of chitosan have a significant effect $(p<0.05)$ to the growth of $S$. thermophillus, but have not resulted the significant effect to the L. bulgaricus ( $p>0.05)$ growth. So, therefore the addition of chitosan and COS as prebiotics for the probiotics were in dose dependant manner. Compare to chitosan commercial, our chitosan production have a good potency to be developed.
\end{abstract}

Keywords: chitosan, oligochitosan, prebiotics, probiotics

\section{INTRODUCTION}

Chitosan is generated from chitin deacetilation that produce some good benefits due to its physicochemistry and biological aspects (Islam et al., 2020) in terms of food industry, pharmacy and environemental agent (Arias et al., 2018). The weakness of this compound is due to the low water solubility with high viscosity (Tanasale et al., 2019). The common strategy is by cutting the $\beta-1,4$ glicosidic bond (Akbari-Alavijeh et al., 2020) and the product called chitooligosaccharide (COS).

Poeple used to get COS by physical treatments such as thermal heating (Yudiati et al., 2018; Rizfa et al., 2020) enzimatic methods (Lee et al., 2008) and chemical reagents such as Hidrogen peroxide $\left(\mathrm{H}_{2} \mathrm{O}_{2}\right)$ (Qin et al., 2002; Rizfa et al., 2020). Tanasale et al. (2019) reported that COS product by using $\mathrm{H}_{2} \mathrm{O}_{2}$ has the molecular weight of $4.2 \times 10^{3}$. The degree of polimerisation was around 2 20 monomers (Liaqat \& Eltem, 2018) with higher bioactivity (Xia et al., 2011).

Research by Lee et al. (2002) revealed that Lactobacillus sp. and Bifidobacterium bifidium growth were stimulated by enzymatic COS, pursuing that COS had a prebiotic function in order to support acid lactic bacteria growth (Ismail et al., 2020). Furhtermore, Soleimani et al. (2017) was also supported this facts. They claimed that COS was triggered the prebiotics growth. Rizfa et al. (2020) stated that alginate oligosaccharide (AOS) depolimerization with $\mathrm{H}_{2} \mathrm{O}_{2}$ was able to 
improve the antioxidant activity. While, Yudiati et al. (2020) was also reported that AOS fulfilled the needs of probiotic commercial bacteria to grow. On the other hand, the exploration of polimerized COS with $\mathrm{H}_{2} \mathrm{O}_{2}$ had not been fully explored yet. Based on this fact, the study on the chitosan and cos potency in different doses and the relation on S. thermophillus dan L. bulgaricus. growth were conducted.

\section{MATERIALS AND METHODS}

Commercial chitosan originally from shrimp shells' waste were obtained from Chitosan Shrimp Shell, Monodon Group Bogor. Lactobacillus bulgaricus FNCC - 0041 and Streptococcus thermophilus FNCC - 0040 were purchased from Microbiology Laboratory, Center of Food Study, Gadjah Mada University.

Shrimp shell was diluted in $3.5 \% \mathrm{NOH}$ at 10:1 (V/W) and followed by heating up at $65^{\circ} \mathrm{C}$ ( $2 \mathrm{hrs}$ ), and cooled down. The solution was then rinsed with aquadest until $\mathrm{pH}$ neutral. The samples was then dried at $100^{\circ} \mathrm{C}$. The deproteinated sample was then diluted with $1 \mathrm{~N} \mathrm{HCl}$ at 15:1 (V/W) and continued by heated up for $30 \mathrm{mns}$. This then followed by rinsing with aquadest (neutral $\mathrm{pH}$ ) and was dried up for $100^{\circ} \mathrm{C}$ to reach the constant weight (Tanasale et al., 2019).

Chitosan extraction was done by diluted chitin in $60 \% \mathrm{NaOH}$ ini 20:1 (V/W) for 6 hrs at $80-100^{\circ} \mathrm{C}$. The neutral filtrate was then filtered and the dried up at $100^{\circ} \mathrm{C}$ to get the constant weight. The depolimerisation was conducted by this procedur. Four grams of chitosan was diluted in $200 \mathrm{~mL}$ of $0.5 \%$ acetic acid and $10 \mathrm{~mL}$ of $\mathrm{H}_{2} \mathrm{O}_{2} 10 \%$ was then added. The solution was mixed and reacted at $100^{\circ} \mathrm{C}$ ( 2 hrs) and were cooled and managed until $\mathrm{pH} 7.0$ by adding $\mathrm{NaOH} 10 \mathrm{~N}$ until the hidrolysate gel has performed (Tian et al., 2004). Precipitated was then conducted by adding alcohol isopropyle (3:1). The pellet was then dried up in the oven at $40^{\circ} \mathrm{C}$ for the constant weight (Uju et al., 2018). The dried chitosan was then grounded with mortar.

The confirmation of chitosan and COS charaterisation was done by Fourier Transform
Infrared Spectrophotometer (Tanasale et al., 2019). Chitosan deacetylation (DD) was determined by base line methods based on this following equation (Khan et al., 2002).

Lactobacillus bulgaricus FNCC-0041 and Streptococcus thermophilus FNCC-0040 was suspended in MRS Broth (de Man, Rogosa and Shape Broth) media and incubated for $48 \mathrm{hrs}$ at $37{ }^{\circ} \mathrm{C}$.

The effectiveness of prebiotics (chitosan and COS) was done by observing the growth of probiotic bacteria in the MRS Broth media with chitosan and COS addition. The $2 \mathrm{~mL}$ bacteria suspension (106 cfu/ml) was put into erlenmeyer. Each erlenmeyer was completed with magnetic stirrer and $40 \mathrm{~mL}$ of MRS Broth containing $0.05 ; 0.1$ and $0.2 \mathrm{mg} / \mathrm{ml}$ chitosan and COS (Yang et al., 2011). This then followed by taking $5 \mathrm{~mL}$ bacterial suspension aseptically at $0,5,10,15,20,25$, dan $30 \mathrm{hrs}$ and then cultured in MRS Agar (de Man, Rogosa and Shape Agar) to get the total plate count. The bacterial specific growth rate ( $\mu$ /hari) was determined at logarithmic phase based on this formula (Pramono et al., 2003)

The bacterial growth peak was determined based on the observation of exponentialy phase until dead phase with linear regression $Y=a x+a b$ (Rosmania \& Yanti, 2019). Data analysis was done by ANOVA with $5 \%$ level of sinificance. The analysis was using Microsoft Excel 2019 software to find out the influence of chitosan and COS to the cultured organisms.

\section{RESULTS AND DISCUSSION}

One of Chitsan and COS Charaterisation is the deacetyltion degree. Generally, the deacetylation degree (DD) of CC, PC and COC, POC were similar i.e. $77.5 \%$, $85 \%$ and $64 \%, 62.5 \%$, respectively (Figure 1 ).

The percentage of DD ini selfproduction and commercial chitosan were in the range of permittable chitosan, which is $>70 \%$ (Dompeipen et al., 2016). Our production of chitosan was only left of $22.5 \%$ of acetyl group. The analysis of FT-IR in all treatments showed the similar signal vibration 
in $400-4000 \mathrm{~cm}^{-1}$ wave number. There were the existence of $\mathrm{O}-\mathrm{H}$ stretching at $3430 \mathrm{~cm}^{-1}$, $\mathrm{C}-\mathrm{H}$ aliphatic $\left(2919,69 \mathrm{~cm}^{-1}\right), \mathrm{N}-\mathrm{H}$ groups at $1618,65 \mathrm{~cm}^{-1}$ and $\mathrm{C}-\mathrm{O}$ streching $\left(1088,23 \mathrm{~cm}^{-}\right.$ 1). The characterisation of functional groups is presented in Figure 2 and Table 1.

The oxidative degradation in depolimerization process using hydrogen peroxide was enable to cut off the polychain polysaccharide in random ways and lead to the degradation of particle size. So, therefore, the production of new compound with lower molecular weight was appeared (Tian et al., 2004, Rizfa et al., 2020). The thermal heating application, in fact, speed up the hydrogen peroxyde decomposition which produce hydrogen ions and anion hydroxyle. Those ions will attempt for further reaction and producing the highly reactive hycroxyle forms (OH) (Qin et al., 2002).

The effect of different concentration of CC in S. thermophillus FNCC - 040 and L. bulgaricus FNCC - 041 growth can be seen in
Figure $3 a$ and b. Meanwhile, the effect of PC in the growth of $S$. thermophillus and $L$. bulgaricus is presented in Figure $4 \mathrm{a}$ and $\mathrm{b}$.

The effect of different concentration of commecial oligochitosan (COC) in $S$. thermophillus and $L$. bulgaricus growth can be seen in Figure $5 a$ and $b$. While, the effect of self production oligochitosan (POC) in the growth of $S$. thermophillus and L. bulgaricus are presented in Figure $6 a$ and $b$.

From those figures, it can be seen that growth of two lactic acid bacteria was normal and expressed in quadratically curve which start as a lag, continued to exponentially, stationary phase and lastly with dead phase. The statistical analysis confirmed that that the addition of CC, PC, COC and POC in two different lactic acid bacteria reached the different results. The growth of $S$. thermophillus was significantly different $(p<0.05)$, while L. bulgaricus was non significantly different. This facts is also denoted in Table 2.

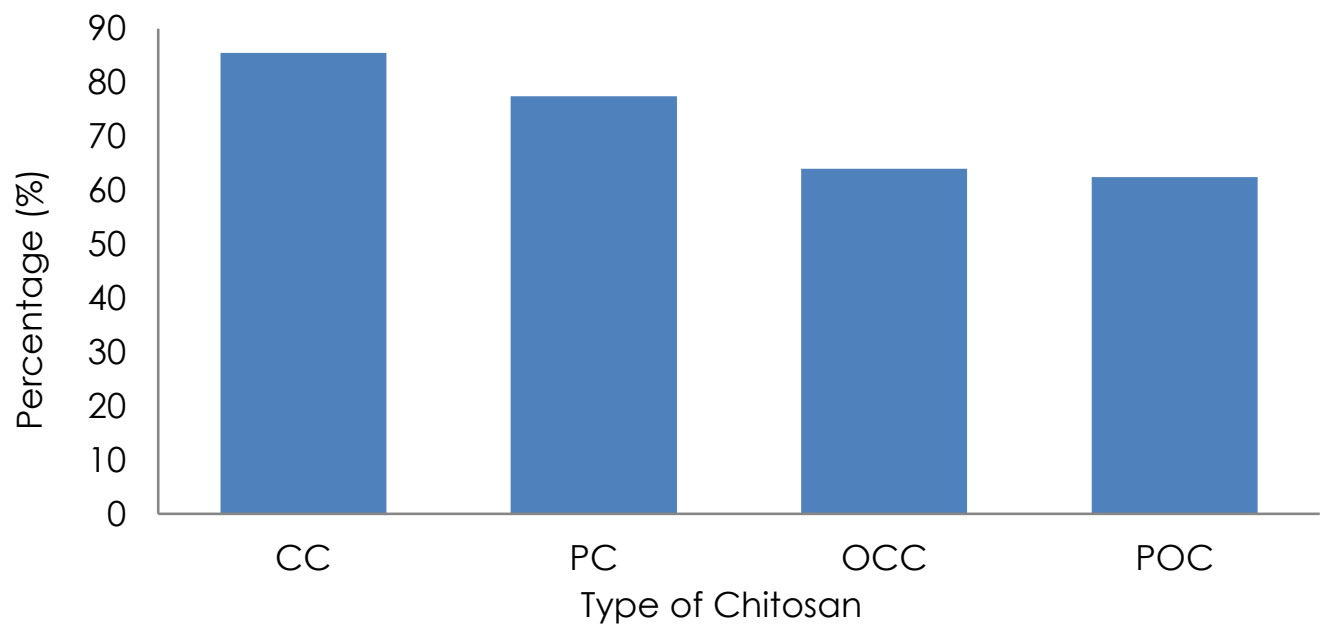

Figure 1. The deacetylation degree of different type of chitosan and COS

Table 1. Characterisation of different type of chitosan

\begin{tabular}{ccccc}
\hline \multirow{2}{*}{ Sampel } & \multicolumn{4}{c}{ Wavenumber $\mathrm{cm}^{-1}$} \\
\cline { 2 - 5 } & O-H stretching & C-H aliphatic & $\mathrm{N}-\mathrm{H}$ & C-O stretching \\
\hline CC & 3405.5 & 2953 & 1639.85 & 1073.49 \\
COC & 3444.02 & 2899 & 1633.78 & 1071.36 \\
PC & 3430.68 & 2919.69 & 1618.65 & 1088.23 \\
POC & 3406.23 & 2927.02 & 1631.28 & 1072.68 \\
\hline
\end{tabular}




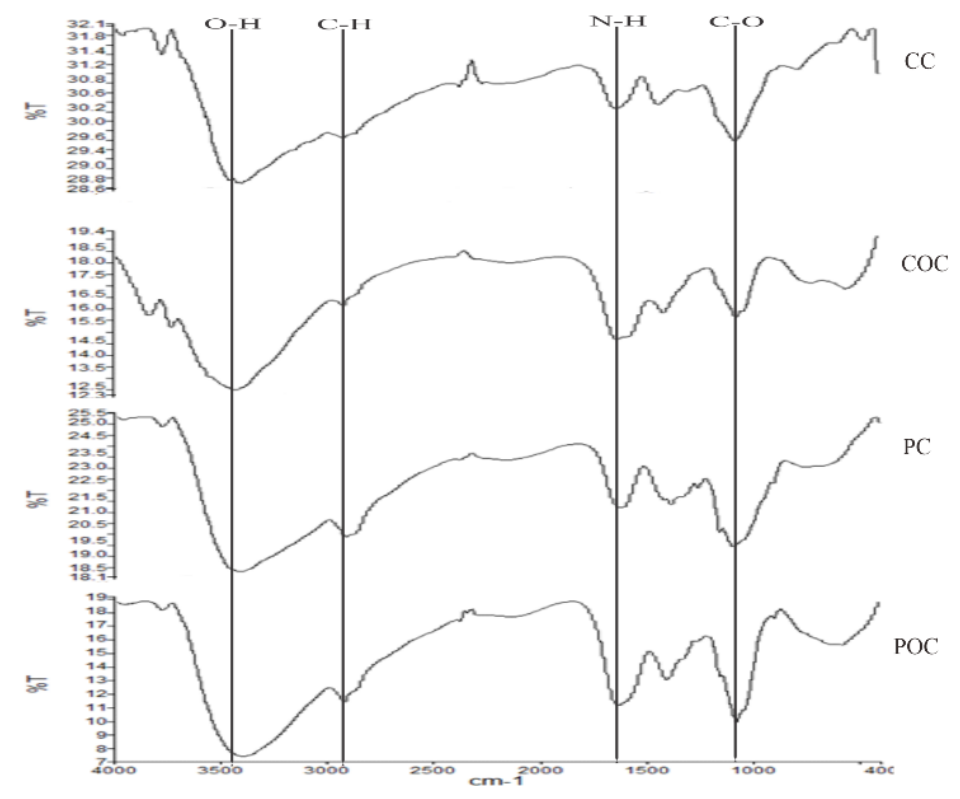

Figure 2. FT-IR spectra vibration of different type of chitosan $\left(400-4000 \mathrm{~cm}^{-1}\right)$

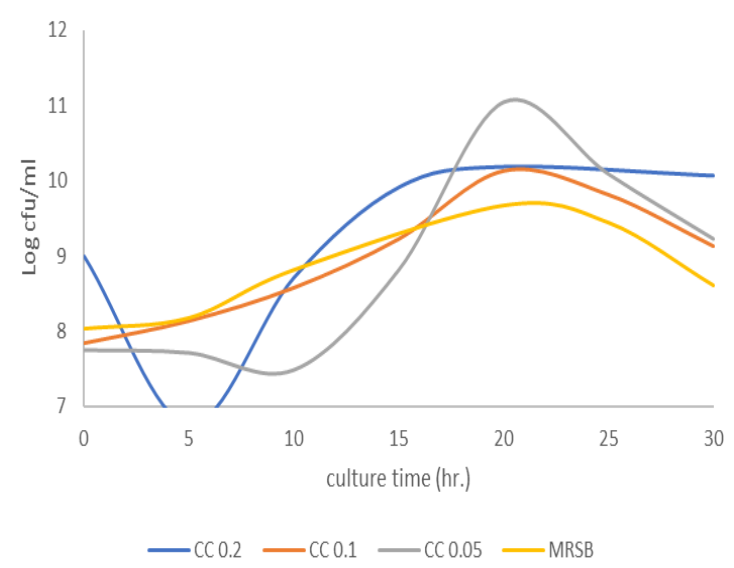

a

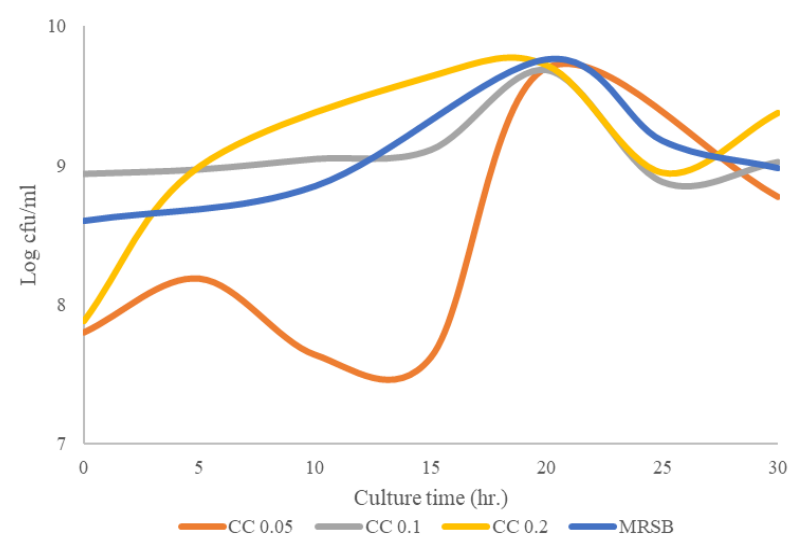

$b$

Figure 3. (a) Growth of S. thermophillus FNCC - 040 and (b) L. bulgaricus FNCC - 041 in different concentration of commercial chitosan

The Effect of Chitosan on the Growth of $S$. thermophillus and $L$. bulgaricus

Chitosan is a low solubility compound and its application for probiotics was done by fermentation process from gut microflora (Tang et al., 2020). Soleimani et al. (2017) stated that the chitosan application at 6.5 $\mathrm{mg} / \mathrm{mL}$ had a good potency as prebiotics compounds due to the ability of Lactobacillus to grow. Additionally, Asim et al. (2020) pursuing that the antibacterial activity of chitosan influence by some factors such as the type of chitosan, the deacetialation degree, $\mathrm{pH}$ and other physicochemically characters. Chitosan was able to immobilise the bacteria by providing the nutritional requirements and as a matrix. This will keep the viability of bacteria (Oktarina et al. (2017). Our present results from Figure 3-6 and Table 2 , supported this finding, though, in detail, the results from different treatments show a slight differences. 


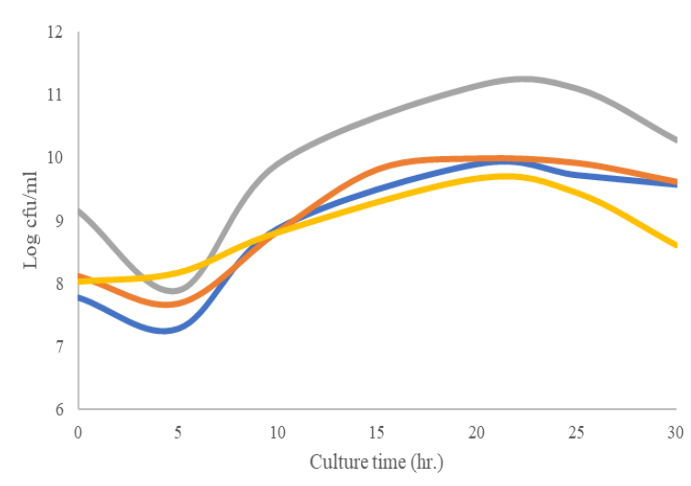

$\longrightarrow \mathrm{PC} 0.05 \leftrightharpoons \mathrm{PC} 0.12 \mathrm{PC} 0.2 \leftrightharpoons \mathrm{MRSB}$

a

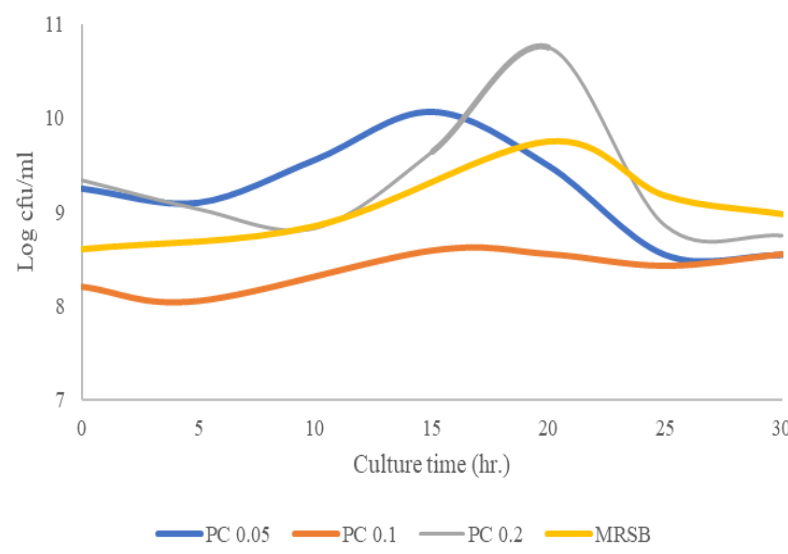

b

Figure 4. (a) Growth of S. thermophillus FNCC - 040 and (b) L. bulgaricus FNCC - 041 at different concentration of self-production chitosan

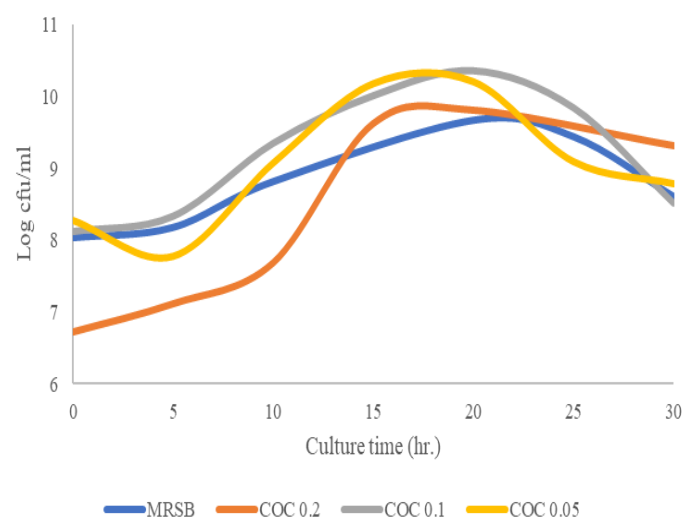

a

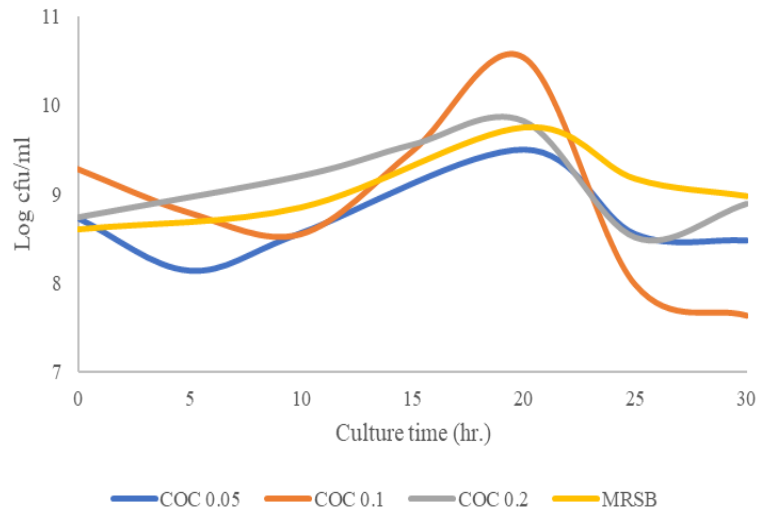

$b$

Figure 5. (a) Growth of S. thermophillus FNCC - 040 and (b) L. bulgaricus FNCC - 041 at different concentration of commercial oligochitosan

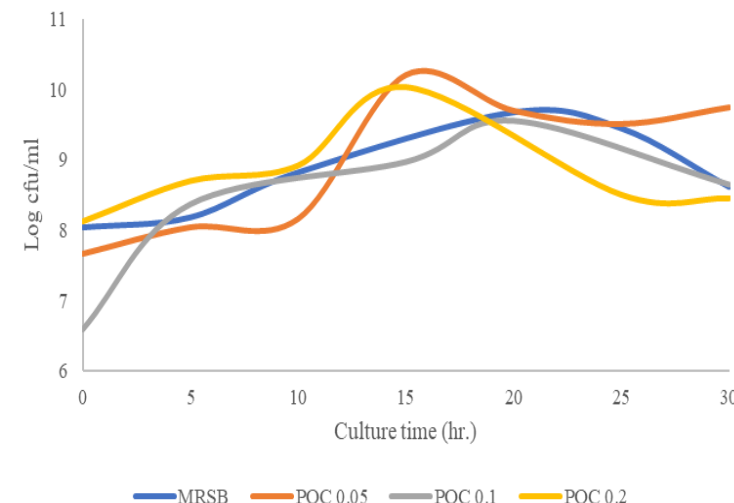

a

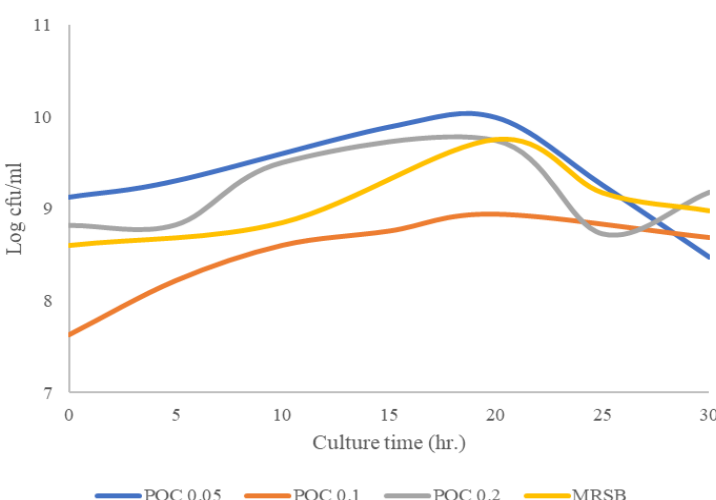

b

Figure 6. (a) Growth of S. thermophillus FNCC - 040 and (b) L. bulgaricus FNCC - 041 at different concentration of self-production oligochitosan 
Table 2. Time of growth peak, cell density and specific growth rate of $S$. thermophillus and $L$. bulgaricus (Log cfu/ml) at different treatment of chitosan

\begin{tabular}{|c|c|c|c|c|c|c|}
\hline \multirow[b]{2}{*}{ Treatment } & \multicolumn{3}{|c|}{ S. thermophillus FNCC - 0040} & \multicolumn{3}{|c|}{ L. bulgaricus FNCC - 0041} \\
\hline & $\begin{array}{l}\text { Peak of } \\
\text { growth } \\
\text { (hrs) }\end{array}$ & Log cfu/ml & SGR $(\mu / \mathrm{hrs})$ & $\begin{array}{l}\text { Peak of } \\
\text { growth } \\
\text { (hrs) }\end{array}$ & Log cfu/ml & SGR $(\mu / h r s)$ \\
\hline CC $0.05 \mathrm{mg} / \mathrm{ml}$ & 20.13 & $10.03 \pm 0.56$ & $0.30 \pm 0.43$ & 21.41 & $8.82 \pm 0.87$ & $0.13 \pm 0.19$ \\
\hline $\mathrm{CC} 0.10 \mathrm{mg} / \mathrm{ml}$ & 20.64 & $9.70 \pm 0.49$ & $0.25 \pm 0.25$ & 19.82 & $9.28 \pm 0.43$ & $0.03+0.42$ \\
\hline $\mathrm{CC} 0.20 \mathrm{mg} / \mathrm{ml}$ & 23.48 & $10.05 \pm 0.47$ & $0.95 \pm 0.41$ & 16.76 & $9.86 \pm 0.04$ & $0.27 \pm 0.46$ \\
\hline PC $0.05 \mathrm{mg} / \mathrm{ml}$ & 21.22 & $9.87 \pm 0.16$ & $1.18 \pm 1.32$ & 14.98 & $8.93 \pm 1.12$ & $0.07 \pm 0.21$ \\
\hline $\mathrm{PC} 0.10 \mathrm{mg} / \mathrm{ml}$ & 21.24 & $10.15 \pm 0.02$ & $0.04 \pm 0.08$ & 17.33 & $8.03 \pm 0.73$ & $0.38 \pm 0.35$ \\
\hline $\mathrm{PC} 0.20 \mathrm{mg} / \mathrm{ml}$ & 22.65 & $10.53 \pm 0.80$ & $0.78 \pm 1.11$ & 19.91 & $9.74 \pm 0.94$ & $0.07 \pm 0.28$ \\
\hline COC $0.05 \mathrm{mg} / \mathrm{ml}$ & 17.54 & $9.72 \pm 0.58$ & $1.37 \pm 0.32$ & 19.08 & $8.65 \pm 0.73$ & $0.51 \pm 0.79$ \\
\hline $\mathrm{COC} 0.10 \mathrm{mg} / \mathrm{ml}$ & 19.72 & $9.69 \pm 0.90$ & $0.46 \pm 0.73$ & 18.89 & $9.60 \pm 0.89$ & $0.11 \pm 0.14$ \\
\hline $\mathrm{COC} 0.20 \mathrm{mg} / \mathrm{ml}$ & 20.61 & $9.40 \pm 0.43$ & $0.02 \pm 0.03$ & 19.12 & $9.26 \pm 0.72$ & $0.01 \pm 0.12$ \\
\hline $\mathrm{POC} 0.05 \mathrm{mg} / \mathrm{ml}$ & 15.44 & $10.20 \pm 0.01$ & $0.05 \pm 0.07$ & 18.53 & $9.54 \pm 0.54$ & $0.14 \pm 1.21$ \\
\hline $\mathrm{POC} 0.10 \mathrm{mg} / \mathrm{ml}$ & 21.15 & $9.14 \pm 0.46$ & $0.13 \pm 0.40$ & 21.09 & $8.51 \pm 0.47$ & $0.28 \pm 0.34$ \\
\hline $\mathrm{POC} 0.20 \mathrm{mg} / \mathrm{ml}$ & 17.48 & $9.58 \pm 0.52$ & $0.42 \pm 0.56$ & 18.17 & $8.92 \pm 0.74$ & $0.31 \pm 0.76$ \\
\hline MRS Broth & 19.69 & $9.29+0.38$ & $0.61+0.81$ & 19.32 & $0.83 \pm 0.87$ & $0.10+0.81$ \\
\hline
\end{tabular}

The S. thermophillus and L. bulgaricus culture in MRS broth-chitosan added media showed the positive growth. The best growth chitosan showed from PC $0.2 \mathrm{mg} / \mathrm{ml}$ treatment aginst $S$. thermophillus (136.2 × $10^{9}$ $\mathrm{cfu} / \mathrm{mL})$. This data suggested that the prebiotics bacteria used this chitosan as their nutrition an certain concentration, similarly our previous findings with alginate (Yudiati et al, 2020). In fact, the DD from our self-production chitosan was $77.5 \%$, which is lower than commercial chitosan (85\%). The higher percentage DD produce the higher antibacterial activity (Jung et al., 2010). Yucel-Falco et al. (2017) informed that lactic acid bacteria was sensitive to the antimicrobial activity in chitosan. Lee et al. (2002) confirmed that chitosan polymers at higher concentration (0.16-0.31\%) showed the inhibition of Lactobacillus sp. and $S$. thermophillus growth culture. Furthermore, Li \& Zhuang. (2020) was also reported the mechanism of chitosan as antibacterial. The action is bonding the negative chemical structure of chitosan with bacterial cell receptor which damage the cell membrane. This will trigger the bacterial cell compound and lead the bacterial death. At a higher concentration, chitosan will be protonated and the cell bacterial surface will be coated to prevent the damage of inner cell bacteria and the positively charged bacteria will be rejected vice versa. So, therefore, this were resulted the prevention of the agglutination forms.

The MRS broth-chitosan added media was significantly improve the $S$. thermophillus growth, but not in L. bulgaricus. Li et al. (2009) informed that the type and dose of probiotic is highly influenced to the effectiveness of nutrition utilization. Probiotics is in fact have the selectivity characters to the prebiotics, including chitosan. This prebiotics can be utilized as nutrition to stimulate growth and cell metabolism of lactic acid bacteria (Pan et al., 2009; Yudiati et al., 2020). On the other hand, it is postulated that $L$. bulgaricus was not utilised the chitosan as their nutrient source and tend to be selective in terms of the prebiotic usage for the similar manners.

\section{The effect of chitooligosaccharide on the growth of $S$. thermophillus and $L$. bulgaricus}

Chitooligosaccharide is water soluble compound, with polimeration degree $<20$ and have the low molecular weight ie. 3.9 $\mathrm{kDa}$ (Liaqat \& Eltem, 2018). COS has proven to have the better prebiotic activity compared to chitosan and marketable standard inuline (Ismail et al., 2020). Moreover, Fernandes et al. (2012) have also stated that chitooligosaccharide is classified 
as the weak prebiotics compared to other oligosaccharides particularly fructooligosaccharide and galactooligosaccharide.

Chitooligosaccharide consists of 18 fold higher sugar reduction compared to chitosan (Ismail et al. 2020). This is also act as the good carbon source for beneficial microbiota growth in intestinum (Kong et al. 2014). Lee et al. (2002) was also reported that chitooligosaccharide able to stimulate the lactic acid bacteria namely Lactobacillus sp. and Bifidobacterium bifidium. The supplementation of chitoologosaccharide in food was able to enhance the growth and density of bacteria from genus Bacteroides, Faecalibacterium, Alistipes, and Prevotella (Liu et al., 2020). Supporting to this reports, Liang et al. (2013) was also stated that chitooligosaccharide enable to stimulate the Lactobacillus paracasei BCRC12193 and Lactobacillus kefir BCRC1401 growth. Type and dose of probiotics usage is highly dependant to its efficiency.

The S. thermophillus and L. bulgaricus culture in MRS Broth media chitooligosaccharide addicted showed the different bacterial growth. S. thermophillus culture in media MRS Broth media with chitosan oligosaccharide commercial at $0.1 \mathrm{mg} / \mathrm{ml}$ showed the highest stationary phase $\left(225.3 \times 10^{8} \mathrm{cfu} / \mathrm{ml}\right)$. In accordance to Li \& Zhuang (2020) chitosan has the higher antibacterial activity than chitosan oligomer. Moreover, the similar authors were also informed that the bactericidal effect of COS is higher in gram positive bacteria rather than gram negative bacteria. Furthermore, the chitooligosaccharide was significantly abled to inhibit the growth of Lactobacillus sp. and S. thermophillus at relatively high concentration $10.63 \%$ ) (Lee et al. 2002)and also in intestinum (Liu et al., 2020).

The MRS broth media addictedchitooligosaccharide showed the increment of $\mathrm{S}$. thermophillus FNCC -0040 at significantly growth and unsignificantly growth on $L$. bulgaricus FNCC - 0041. Research by Lee et al. (2002), confirmed that chitooligosaccharaide from depolimerisation enzimatically process with polimerisation degree at 2-8 which use as prebiotics, do not inhibit the prebiotic growth.
It has been predicted that $L$. bulgaricus FNCC - 004lcan not efficiently utilize the nutrient of chitooligosaccharide from $\mathrm{H}_{2} \mathrm{O}_{2}$ polimerisation for growth and cell metabolism. On the other hand, the S. thermophillus FNCC - 0040 culture was managed to increase the growth significantly due to its ability to utilize chitooligosaccharide as nutrition to stimulate in the same manner.

Sangwan et al. (2014) confirmed that $S$. thermophillus produce high $\beta$-galactocide enzyme. It is postulated these probiotic bacteria produced this enzyme in the media and this enzyme supported the utilization chitosan and oligosaccharide as nutreints for their growth.

\section{CONCLUSION}

Chitosan and Chitooligosaccharide added at $0.05 ; 0.1$; dan $0.2 \mathrm{mg} / \mathrm{ml}$ in MRS broth for Streptococcus thermophillus FNCC 0040 had the significantly effect $(p<0,05)$ on growth and have a good potency as prebiotics. Chitosan and Chitooligosaccharide added at $0.05 ; 0.1$; and $0.2 \mathrm{mg} / \mathrm{ml}$ in MRS broth for Lactobacillus bulgaricus FNCC 0041 had a non significantly effect $(p>0,05)$ on growth. The application of chitosan and chitooligochitosan at the correct concentration was able to support the probiotic bacteria growth without any antibacterial activity. In the future, our selfproduction chitosan promising a good potency to explore and develop in further aspects.

\section{REFERENCES}

Akbari-Alavijeh, S., Shaddel, R., \& Jafari, S.M. 2020. Encapsulation of food bioactives and nutraceuticals by various chitosanbased nanocarriers. Food Hydrocolloids, 105:105774. doi : 10.1016/j.foodhyd.2020. 105774

Arias, J.L., de O., Schneider, A., BatistaAndrade, J.A., Vieira, A.A., Caldas, S.S. \& Primel, E.G. 2018. Chitosan from shrimp shells: A renewable sorbent applied to the clean-up step of the QUEChERS method in order to determine multiresidues of veterinary drugs in different types of milk. Food Chemistry, 240:1243- 
1253. doi : 10.1016/j.foodchem.2017.08.041

Asim, M., Mariotti, C.E., Conti, B. \& Boccaccini, A. R. 2020. Electrophoretic deposition of ferulic acid loaded bioactive glass / chitosan as antibacterial and bioactive composite coatings. Surface \& Coatings Technology, 405:120. doi : 10.1016/j.surfcoat.2020.126657

Dompeipen, E.J., Kamimudin, M. \& Dewa, R. P. 2016. Isolation of Chitin and Chitosan from Waste of Skin Shrimp. Majalah BIAM, 12(1):32-38.

Fernandes, J.C., Eaton, P., Franco, I., Ramos, Ó.S., Sousa, S., Nascimento, H., Gomes, A., Santos-Silva, A., Xavier Malcata, F. \& Pintado, M.E. 2012. Evaluation of chitoligosaccharides effect upon probiotic bacteria. International Journal of Biological Macromolecules, 50(1):148152. doi : 10.1016/j.ijbiomac.2011.10.011

Islam, M.M., Shahruzzaman, M., Biswas, S., Nurus Sakib, M., \& Rashid, T.U. 2020. Chitosan based bioactive materials in tissue engineering applications-A review. Bioactive Materials, 5(1):164-183. doi : 10.1016/j.bioactmat.2020.01.012

Ismail, S.A., El-Sayed, H.S., \& Fayed, B. 2020. Production of prebiotic chitooligosaccharide and its nano/microencapsulation for the production of functional yoghurt. Carbohydrate Polymers, 234:1 15941. doi : 10.1016/j.carbpol.2020.115941

Jung, E.J., Youn, D.K., Lee, S.H., No, H.K., Ha, J. G., \& Prinyawiwatkul, W. 2010. Antibacterial activity of chitosans with different degrees of deacetylation and viscosities. International Journal of Food Science and Technology, 45(4):676-682. doi : 10.1111/j.1365-2621.2010.02186.x

Khan, T.A., Peh, K.K., \& Ch'ng, H.S. 2002. Reporting degree of deacetylation values of chitosan: The influence of analytical methods. Journal of Pharmacy and Pharmaceutical Sciences, 5(3):205212.

Kong, X.F., Zhou, X.L., Lian, G.Q., Blachier, F., Liu, G., Tan, B. E., Nyachoti, C. M., \& Yin, Y. L. 2014. Dietary supplementation with chitooligosaccharides alters gut microbiota and modifies intestinal luminal metabolites in weaned Huanjiang minipiglets. Livestock Science, 160(1):97-101. doi : 10.1016/j.livsci.2013.11.023

Lee, D. X., Xia, W. S., \& Zhang, J.L. 2008.
Enzymatic preparation of chitooligosaccharides by commercial lipase. Food Chemistry, 111(2):291-295. doi : 10.1016/j.foodchem.2008.03.054

Lee, H.W., Park, Y.S., Jung, J.S., \& Shin, W.S. 2002. Chitosan oligosaccharides, dp 2-8, have prebiotic effect on the Bifidobacterium bifidium and Lactobacillus $\mathrm{sp}$. Anaerobe, 8(6):319-324. doi : 10.1016/\$10 75-9964(03)00030-1

Li, Jianhui, \& Zhuang, S. 2020. Antibacterial activity of chitosan and its derivatives and their interaction mechanism with bacteria: Current state and perspectives. European Polymer Journal, 138:109984. doi : 10.1016/j.eurpolymj.2020.109984

Li, J., Tan, B., \& Mai, K. 2009. Dietary probiotic Bacillus OJ and isomaltooligosaccharides influence the intestine microbial populations, immune responses and resistance to white spot syndrome virus in shrimp (Litopenaeus vannamei). Aquaculture, $291(1-2): 35-40$. doi : 10.1016/j.aquaculture. 2009.03.005

Liang, T., Liu, C., Wu, C., \& Wang, S. 2013. Applied development of crude enzyme from Bacillus cereus in prebiotics and microbial community changes in soil. Carbohydrate Polymers, 92(2):2141-2148. doi : 10.1016/j.carbpol.2012.11.097

Liaqat, F., \& Eltem, R. 2018. Chitooligosaccharides and their biological activities: A comprehensive review. Carbohydrate Polymers, 184:243-259. doi : 10.1016/j. carbpol.2017.12.067

Liu, W., Li, X., Zhao, Z., Pi, X., Meng, Y., Fei, D., Liu, D., \& Wang, X. 2020. Effect of chitooligosaccharides on human gut microbiota and antiglycation. Carbohydrate Polymers, 242(198). doi : 10.1016/j.carbpol.2020.116413

Rosmania \& Yanti, F. 2019. Perhitungan Jumlah Bakteri di Laboratorium Mikrobiologi Menggunakan Pengembangan Metode Spektrofotometri. Jurnal Penelitian Sains, $21(3): 163-167$.

Oktarina, E., Adrianto, R., \& Setiawati, I. 2017. Immobilization of Bacteria on ChitosanAlginate and Chitin-Alginate. Tegi, 9(2):18.

Pan, X.D., Chen, F. Q., Wu, T.X., Tang, H.G., \& Zhao, Z.Y. 2009. Prebiotic oligosaccharides change the concentrations of shortchain fatty acids and the microbial 
population of mouse bowel. Journal of Zhejiang University: Science B, 10(4):258263. doi : 10.1631/jzus.B0820261

Pramono, Y.B., Harmayani, E., \& Utami, T. 2003. Kinetika Pertumbuhan Lactobacillus plantarum dan Lactobacillus sp. Pada Media MRS Cair. Jurnal Teknologi Dan Industri Pangan, XIV(1):46-50.

Qin, C.Q., Du, Y. M., \& Xiao, L. 2002. Effect of hydrogen peroxide treatment on the molecular weight and structure of chitosan. Polymer Degradation and Stability. doi : 10.1016/S0141-3910(02)00 016-2

Rizfa, M.S., Yudiati, E., \& Wijayanti, D.P. 2020. Improving The Antioxidant Activity of Sodium Alginate from Sargassum sp. by Thermal Heating and Chemical Methods. Jurnal Kelautan Tropis, 23(3):284-290. doi : 10.14710/jkt.v23i3.8946.

Sangwan, V., Tomar, S.K., Ali, B., Singh, R.R.B., \& Singh, A.K. 2014. Production of $\beta$ galactosidase from streptococcus thermophilus for galactooligosaccharides synthesis. Journal of Food Science and Technology, 52(7):4206-4215. doi : 10.100 7/s13197-014-1486-4

Soleimani, N.A., Kermanshahi, R.K., \& Yakhehali, B. 2017. The Effect of Prebiotic Chitosan on the growth and antimicrobial characteristic of Probiotic lactobacilli. Iranian Journal of Medical Microbiology, 10(6):34-43.

Tanasale, M.F.J.D.P., Bijang, C.M., \& Rumpakwara, E. 2019. Preparation of Chitosan with Various Molecular Weight and Its Effect on Depolymerization of Chitosan with Hydrogen Peroxide using Conventional Technique. International Journal of ChemTech Research, 12(01): 112-120. doi : 10.20902/ijctr.2019. 120113

Tang, D., Wang, Y., Kang, W., Zhou, J., Dong, R., \& Feng, Q. 2020. Chitosan attenuates obesity by modifying the intestinal microbiota and increasing serum leptin levels in mice. Journal of Functional
Foods, 64(44):103659. doi : 10.1016/j.jf.20 19.103659

Tian, F., Liu, Y., Hu, K., \& Zhao, B. 2004. Study of the depolymerization behavior of chitosan by hydrogen peroxide. Carbohydrate Polymers, 57(1):31-37. doi : 10.1016/j.carbpol.2004.03.016

Uju, U., Santoso, J., \& Raprap, I.R.H. 2018. Depolimerisasi Karaginan Murni dengan Hidrogen Peroksida dan Akselerasi Gelombang Ultrasonik. Jurnal Pengolahan Hasil Perikanan Indonesia, 21 (1):156. doi : 10.17844/jphpi.v21i1.21540

Xia, W., Liu, P., Zhang, J. \& Chen, J. 2011. Biological activities of chitosan and chitooligosaccharides. Food Hydrocolloids, 25(2):170-179. doi : 10.1016/j.foodhyd.20 10.03.003

Yang, B., Prasad, K.N., Xie, H., Lin, S., \& Jiang, Y. 2011. Structural characteristics of oligosaccharides from soy sauce lees and their potential prebiotic effect on lactic acid bacteria. Food Chemistry, 126(2):590-594. doi : 10.1016/j.foodchem. 2010.11 .048

Yucel-Falco, C., Sotres, J., Rascón, A., Risbo, J., \& Cárdenas, M. 2017. Design of a potentially prebiotic and responsive encapsulation material for probiotic bacteria based on chitosan and sulfated $\beta$-glucan. Journal of Colloid and Interface Science, 487:97-106. doi : 10.10 16/j.jcis.2016.10.019

Yudiati, E., Pringgenies, D., Djunaedi, A., Arifin, Z., \& Sudaryono, A. 2018. Free Radicals Scavenging Activities of Low Molecular Weight Sodium Alginate (LMWSA) from Sargassum polycystum, Produced by Thermal Treatment. Aquacultura Indonesiana, 19(1): 21-27. doi : 10.21534 /ai.v19i1.121.

Yudiati, E., Subagiyo, S., \& Djarod, M.S.R. 2020. Preliminary Study of Polysaccharide and Oligosaccharide Alginate (AOS) as Prebiotic of Probiotic Bacteria. Jurnal Kelautan Tropis, 23(2):234-238. doi : 10.14 710/jkt.v23i2.7674 